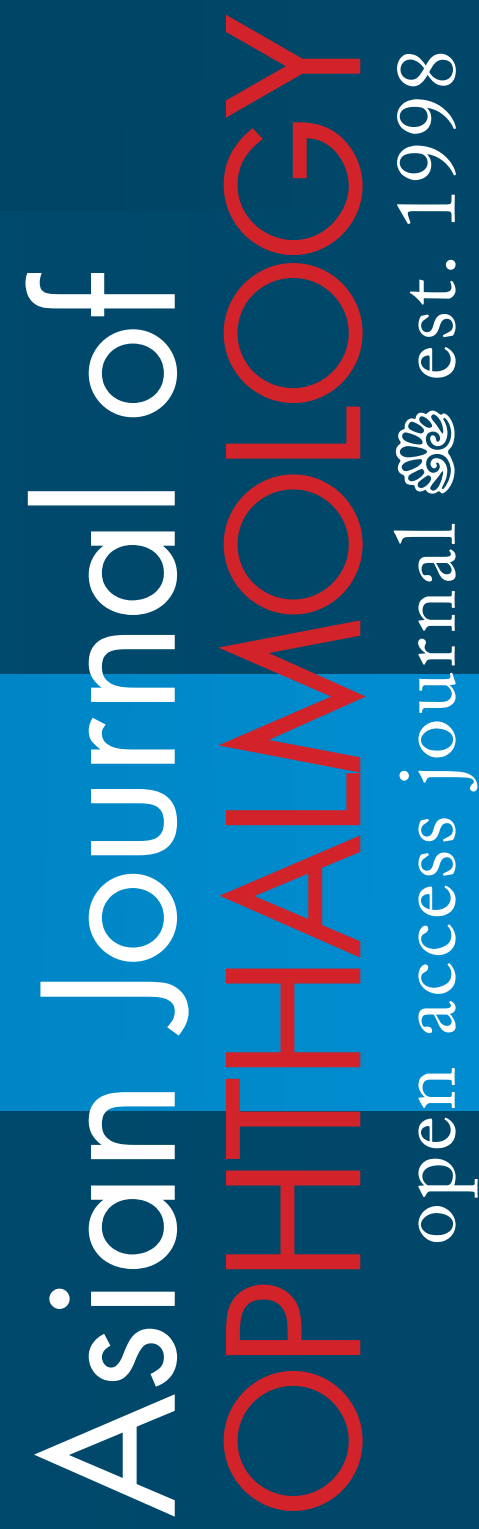

Volume $13 \cdot$ Issue $4 \cdot 2014 \cdot 1560-2133$ 


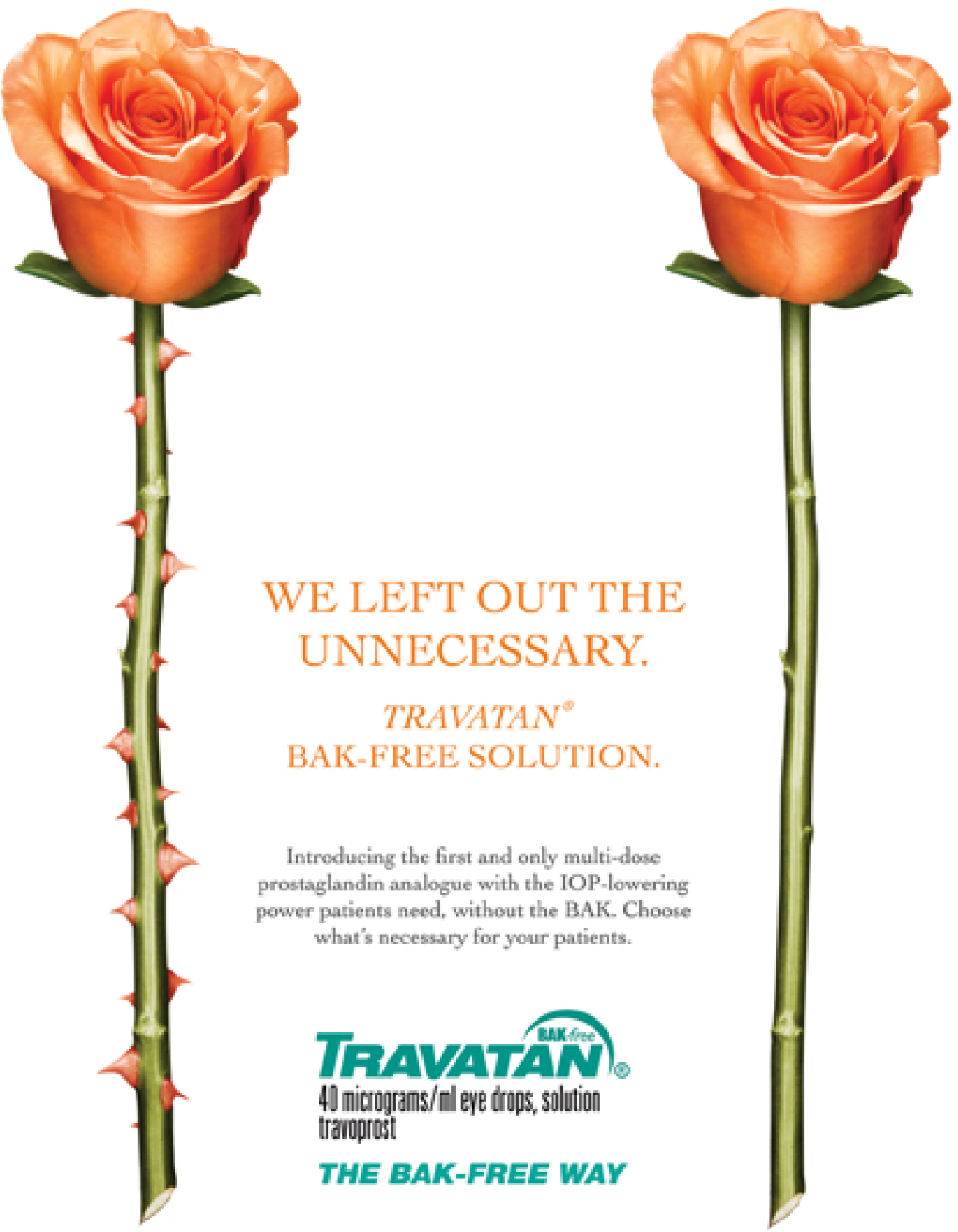

For more information on the product please contact your local Alcon' representative 


\section{Asian Journal of OPHTHALMOLOGY}

Submit your article now to the

Asian Journal of

a peer-reviewed online open access journal.

There are no publication costs, hidden fees or charges.

\section{Chief editor: Paul Chew}

The objectives of Asian Journal of Ophthalmology are as follows:

- To provide a platform for the publication of information with a focus on Ophthalmology in Asia

- To disseminate information that will improve the care of patients with all types of ophthalmological disorders, with a special focus on glaucoma

- To increase the understanding of such disorders through reporting of educational activities

- To publish the results of research programmes to expand knowledge about the causes, prevention, and treatment of ophthalmological disorders

- To work closely with Asian and international researchers to achieve these aims

- To provide a forum for young and relatively inexperienced researchers to present their research results as Original Articles via an international platform

- To maintain and promote relationships with any organisation with similar goals.

For more information, an article template and submission guidelines, see www.asjoo.com

PUBLICATION SCHEDULE 2014-2015:

2014

September 2014

September 2014

October 2014

December 2014

14-1

Highlights print issue

(APGC)

14-2

14-3
2015

February $2015 \quad$ 14-4: Special issue on

Generic Medications

April 2015

July 2015

October 2015

January 2016
15-1

15-2

15-3

15-4

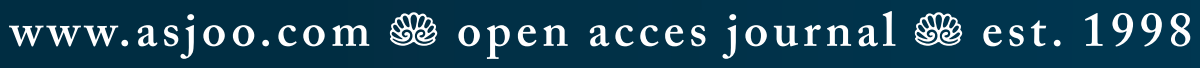




\title{
Awareness and perception of budding doctors: A focal scenario on eye donation
}

\author{
Mausumi Basu, ${ }^{1}$ Palash Das, ${ }^{2}$ Biman Roy, ${ }^{3}$ Jayanta Kumar Baruah ${ }^{4}$ \\ ${ }^{1}$ Associate Professor, Department of Community Medicine, IPGMER, Kolkata, India; \\ ${ }^{2}$ Associate Professor, Department of Community Medicine, College of Medicine \\ and Sagore Dutta Hospital, Kamarhati, Kolkata, India; ${ }^{3}$ Assistant Professor, Dept. of \\ Physiology, Maldah Medical College, West Bengal, India; ${ }^{4}$ RMO-cum-Clinical Tutor, \\ Dermatology, Malda Medical College, West Bengal, India
}

\begin{abstract}
Background: Diseases affecting the cornea constitute a major cause of blindness. Corneal transplantation offers the potential for sight restoration. Due to non-availability of healthy cornea, many people continue to live in a dark world.

Objectives: To assess the awareness and perception of undergraduate medical students towards eye donation.

Methods: A cross-sectional study was conducted among undergraduate medical students of Kolkata on August 2010 using a pre-designed, pre-tested, semi-structured, self-administered questionnaire. The data were analyzed using Epi-info software package version 6.04. Results: Almost all (98.9\%) participants knew that eyes can be donated and $70.8 \%$ were aware at the time of eye collection. However, only $43.7 \%$ respondents knew whom to approach for pledging their eyes for donation; $80.7 \%$ were either willing $(76.0 \%)$ or had already pledged (4.7\%) to donate their eyes. Television was the major source $(78.1 \%)$ of information on eye donation. Nobility was the main motivation (87.7\%) and $75.5 \%$ felt the need for helping the blind. Of these medical students, $19.3 \%$ were unaware and did not pledge eye donation due to objection by family members and dislike of the idea of separating their eyes.

Conclusion: The present study revealed that medical students were well aware of eye donation with a favorable attitude towards it and most of them were inclined to pledge for eye donation. The perceived reasons for not donating eyes need to be considered while creating awareness about eye donation in the community. Students can be actively involved as volunteers in eye donation campaigns and after proper training in counselling techniques, they can act as counsellors for eye donation activities.
\end{abstract}

Key words: Blindness, corneal transplant, eye donation, medical students

\section{Introduction}

Using the definition of blindness from International Classification of Diseases 10 (Update and Revision 2006), ${ }^{1}$ globally the number of visually impaired is estimated to be 285 million, 39 million of whom are blind and 246 million have moderate to severe visual impairment. In the South-East Asia Region (SEAR) of the World Health Organization (WHO), apart from India, 27.9 million people are visually impaired,

Correspondence: Dr. Palash Das, Associate Professor, Department of Community Medicine, College of Medicine and Sagore Dutta Hospital, Kamarhati, Kolkata - 700058, India.

E-mail: palashdasdr@gmail.com 
3.9 million of whom are blind and 23.9 million have low vision. In India alone, 62.6 million people are visually impaired, 8 million of whom are blind and 54.5 million have low vision. ${ }^{2}$ The different causes of blindness in India are cataract (62.6\%); refractive errors (19.7\%); glaucoma (5.8\%); corneal pathologies $(0.9 \%){ }^{3}$ The prevalence of blindness is $0.6 \%$ and the prevalence of low vision is $2.0 \%{ }^{4}$

In West Bengal, the prevalence rate of blindness has been lowered from $1.49 \%$ to $0.63 \%$ and the goal $(0.3 \%)$ is expected to be achieved by the year 2020.5

Diseases affecting the cornea constitute a major cause of blindness worldwide, second only to cataract in overall importance. According to WHO it is the fourth cause of blindness globally, after cataract, glaucoma and age related macular degeneration. ${ }^{2}$ The global causes of corneal blindness are: trachoma, xerophthalmia and ophthalmia neonatorum, onchocerciasis, leprosy and the use of harmful traditional eye medicines. ${ }^{6}$ Corneal transplantation offers the potential for sight restoration to those who are blind from corneal diseases and two persons can be benefitted from a single donor. In spite of this, it is a sad fact that due to non-availability of healthy cornea many people continue to live in a dark world. The WHO reports that corneal blindness affects more than ten million people worldwide, but only 100,000 receive corneal transplants each year. ${ }^{7,8}$

As many as three million people can benefit from corneal transplantation in cases where lack of awareness is the hindrance. ${ }^{9}$ One hundred thousand corneas are needed, but only about 10,000 are collected in India. ${ }^{10}$ Only $30 \%$ of donated eyes are used; the rest are either discarded for not being in good shape or sent to medical colleges for educational purposes. ${ }^{11}$ Until 2010, there was an upward trend in the number of corneal donations. ${ }^{12}$ The number of corneas harvested dropped in 2010-11. ${ }^{13}$ If only half the deaths in India would be leading to corneal donation, the waiting list could be done with in just months. ${ }^{14}$ Eye donation fortnight is being organized in this country from $25^{\text {th }}$ August to $8^{\text {th }}$ September each year for last 27 years. ${ }^{15}$

Medical students are the budding physicians of the future who constitute a major potential force to increase the rate of eye donation. They have the opportunity to counsel and motivate the patients and their relatives to donate eyes. To do this, they themselves should be well aware of the need of eye donation, the success of eye transplantation and proper utilization of corneal tissue. Very few studies have been conducted on this topic among medical students in India and in West Bengal, including Kolkata.

In this context, the present study was conducted to assess the awareness and knowledge of undergraduate medical students of tertiary care hospitals towards eye donation and corneal transplantation and the willingness to donate eyes.

\section{Materials and methods}

Type of study: observational, descriptive.

Study design: cross-sectional.

Places of study: IPGMER and Midnapore Medical College, Paschim Medinipur, West Bengal. 
Study population: 400 MBBS students of medical colleges. A convenient sampling technique was followed.

Study tool: pre-designed and pre-tested semi-structured self-administered questionnaire.

Outcome variables: student's knowledge and awareness regarding social and technical aspects of eye donation and corneal transplantation; their intension to donate eyes.

Explanatory variables: demographic details, perceived reasons for eye donation by donors, perceived reasons for not donating eyes and sources of information.

Study duration: included preparatory phase and designing and pre-testing of the questionnaire, data collection, analysis of data and report writing and it required one month time duration. The study was conducted in August 2012.

Data collection was done through a self-administered questionnaire. The students were approached, requested to provide data and explained on the issue of anonymity and privacy. Three hundred eighty-four students responded correctly without missing information.

Inclusion criteria: All the students who were present and gave the consent on the days of data collection.

Exclusion criteria: The students who refused to answer the questionnaire and who were unavailable at the time of data collection (three attempts).

Data management and statistical analysis: Data collection was done by way of selfadministered questionnaires. Compilation in the master sheet, tabulation, analysis, interpretation was done through Epi-Info software package version 6.04. Proportion was calculated.

Ethical committee approval: The study got permission from the principals and a proposal has been sent to the ethical committee for approval. The study was carried out according to the ethical guidelines for biomedical research on human subjects (2000).

\section{Results}

Of the 400 students, 384 responded correctly in the study (response rate $96 \%$ ). The respondents belonged to the age group of 19 to 21 years. Two hundred sixty-four were male (68.7\%), 120 were female (31.3\%).

The relevant responses on knowledge about eye donation by the 384 medical students were considered in the study. Almost all participants (98.9\%) were aware of the existence and practice of eye donation and knew that eyes can be donated only after death. Ideally eyes should be collected within six hours of death and that is fairly well known to $70.8 \%$ students. Only $25 \%$ of the students knew that 70 years is the ideal donor age limit for corneal transplantation. Of the students, $54.6 \%$ were aware that after death the donor's eyes should be kept closed while waiting for the donation. The students were not very well informed about the transportation and storage of the donated eyes, with the medium of transportation known to only $34.4 \%$ students. The respondents were somewhat aware of the ocular (49.4\%) and systemic contra-indications (87.5\%) of eye donation (Table 1 ). 
Table 1. Responses to the questionnaire - awareness and knowledge on eye donation $(n=384)$.

\begin{tabular}{|c|c|c|}
\hline Characters & Number responded & Percentage \\
\hline Eyes can be donated only after death & 380 & 98.9 \\
\hline $\begin{array}{l}\text { Ideal time for collection of donated } \\
\text { eyes is within six hours after death }\end{array}$ & 272 & 70.8 \\
\hline Person who can give consent & 334 & 87.0 \\
\hline $\begin{array}{l}\text { Knows institution where to be } \\
\text { contacted for eye donation }\end{array}$ & 168 & 43.7 \\
\hline Name some eye banks of Kolkata & 124 & 32.3 \\
\hline $\begin{array}{l}\text { Age limit of donor for corneal } \\
\text { transplantation }\end{array}$ & 96 & 25.0 \\
\hline $\begin{array}{l}\text { Knows that after death donor's eye } \\
\text { should be kept closed }\end{array}$ & 210 & 54.6 \\
\hline Knows which part of eye is removed & 330 & 86.0 \\
\hline $\begin{array}{l}\text { Knows which part of eye is } \\
\text { transplanted }\end{array}$ & 352 & 91.6 \\
\hline Knows medium of transportation & 132 & 34.4 \\
\hline $\begin{array}{l}\text { Knows that eye can be stored up to } 24 \\
\text { hours }\end{array}$ & 218 & 56.8 \\
\hline $\begin{array}{l}\text { Knows how storage time can be } \\
\text { prolonged }\end{array}$ & 194 & 50.5 \\
\hline $\begin{array}{l}\text { Knows ocular contra-indications of } \\
\text { cornea transplantation }\end{array}$ & 190 & 49.4 \\
\hline $\begin{array}{l}\text { Knows systemic contra-indications of } \\
\text { eye transplantation }\end{array}$ & 336 & 87.5 \\
\hline
\end{tabular}

The study revealed that $90.6 \%$ agreed that there was shortage of eye donors in India and $80.7 \%$ were either willing $(76 \%)$ or had already pledged to donate their eyes (4.7\%).

Different knowledge (eye shortage, willing to donate) was seen among the participants (Table 2). Television was the major source of information on eye donation for 78.1\% students (Table 3 ).

The specification of perceived reasons for eye donation by the donors was assessed. Noble intentions $(87.7 \%)$ was the main motivation for donation and $75.5 \%$ felt the need for helping the blind (Table 4).

The specification of the $19.3 \%$ medical students who would not pledge their eyes for donation was identified with respect to the reasons for not doing so. Their 
views about lack of eye donation were variable with a majority $(74.7 \%)$ citing lack of awareness as the main reason (Table 5).

Table 2. More responses bordering on knowledge of eye donation/corneal transplant $(n=384)$.

\begin{tabular}{|l|l|l|}
\hline Characters & Number responded & Percentage \\
\hline Knows a person who has donated eyes & 68 & 17.7 \\
\hline $\begin{array}{l}\text { Knows someone who has received a } \\
\text { donated eye }\end{array}$ & 00 & 0 \\
\hline Willing to donate eyes & 292 & 76.0 \\
\hline Already pledged to donate eyes & 18 & 4.7 \\
\hline Willing to donate close relative's eyes & 270 & 70.3 \\
\hline Knows there is an eye shortage in India & 348 & 90.6 \\
\hline $\begin{array}{l}\text { Awareness about selling and buying of } \\
\text { donor eyes }\end{array}$ & 60 & 15.6 \\
\hline
\end{tabular}

Table 3. Source of information on eye donation $(n=384)$.*

\begin{tabular}{|l|l|l|}
\hline Source & Number & Percentage \\
\hline $\begin{array}{l}\text { Television } \\
\text { Radio }\end{array}$ & $\begin{array}{l}300 \\
32\end{array}$ & $\begin{array}{l}78.1 \\
8.3\end{array}$ \\
\hline Newspaper & 272 & 70.8 \\
\hline Magazines & 176 & 45.8 \\
\hline Posters & 106 & 27.6 \\
\hline Friends/Neighbors & 156 & 40.6 \\
\hline Relatives & 106 & 27.7 \\
\hline Doctor & 76 & 19.8 \\
\hline Hospitals & 14 & 3.6 \\
\hline Pamphlets & 90 & 23.4 \\
\hline Seminars/Lectures & 04 & 1.0 \\
\hline Family members & 52 & 13.5 \\
\hline Nurse & 14 & 3.6 \\
\hline Health workers & 94 & 24.5 \\
\hline
\end{tabular}

*Multiple Responses 
Table 4. Distribution of perceived reasons for donating eyes by donors $(n=310) . \#$

\begin{tabular}{|l|l|l|}
\hline Perceived Reason * & Number & Percentage \\
\hline Eye donation is a noble work & 272 & 87.7 \\
\hline Gives pleasure to help the blind & 234 & 75.5 \\
\hline To set an example & 72 & 23.2 \\
\hline To get popularity & 04 & 1.3 \\
\hline $\begin{array}{l}\text { A friend/relative has donated eye } \\
\text { donated eye }\end{array}$ & 64 & 20.6 \\
\hline Impressed after reading an article & 00 & 0.0 \\
\hline $\begin{array}{l}\text { Impressed after attending a seminar/ } \\
\text { lecture }\end{array}$ & 80 & 30.9 \\
\hline Impressed after seeing a movie & 42 & 25.8 \\
\hline
\end{tabular}

\# Included students who have either pledged or are willing to donate eyes.

* Multiple Responses

Table 5. Distribution of perceived reasons for not willing to donate eyes $(n=74)$.*

\begin{tabular}{|l|l|l|}
\hline Perceived reason & Number & Percentage \\
\hline Lack of awareness & 56 & 74.7 \\
\hline Objection by family members & 20 & 27.0 \\
\hline Feels body ill-treated by eye donation & 08 & 10.8 \\
\hline Religious restrictions & 12 & 16.2 \\
\hline $\begin{array}{l}\text { Unsuitability to donate eyes due to } \\
\text { health problems }\end{array}$ & 10 & 13.5 \\
\hline $\begin{array}{l}\text { Dislike of separating eyes from the } \\
\text { body }\end{array}$ & 14 & 18.9 \\
\hline $\begin{array}{l}\text { Signing eye donation card is like } \\
\text { signing death certificate }\end{array}$ & 06 & 8.1 \\
\hline Corneal transplant gives poor result & 00 & 0.0 \\
\hline
\end{tabular}

* Multiple Responses

\section{Discussion}

There are an estimated 4.6 million corneal blind people in India and 20,000 new victims join yearly. The good news is that almost 66 percent of the cases are preventable or curable if basic precautions are taken. Thus as many as 3 million people 
can benefit from corneal transplantation. Yet, no more than 5000 corneal grafts are performed annually. The reason? Lack of awareness!' In a New York Times article in 2008, the president of the International Agency for the Prevention of Blindness, Dr. Nag Rao, said that in India 100,000 corneas are needed for transplants each year, but only about 10,000 are collected each year - and fewer than 5000 transplant operations are being performed annually. ${ }^{10}$ According to the Union health ministry's own analysis, only $30 \%$ of donated eyes are used for treatment of corneal blindness. The rest are either discarded for not being in good shape, or sent to medical colleges for educational purposes. ${ }^{11}$

Until 2010, there was an upward trend in the number of corneal donations. ${ }^{12}$ Despite the growing spread of awareness campaigns, the country has registered a dip of $3.5 \%$ in the number of corneal donations in the last year, according to the latest government statistics. The number of corneas harvested dropped from 46,589 in $2009-10$ to 44,926 corneas in $2010-11 .^{13}$

In fact, in India, an average of only 38,000 corneas are donated annually, thus it will take 112 years for all corneal blind in India to get new corneas. If only half the deaths in India led to corneal donation, the waiting list could be wiped out in just months. ${ }^{14}$ It was found that of the total number who pledged to donate their eyes, less than $1 \%$ was actually donated finally, according to Union Health ministry officials (August 26, 2011). ${ }^{11}$ 'Eye donation fortnight' is organized from $25^{\text {th }}$ August to $8^{\text {th }}$ September every year to promote eye donation. Gujarat, Tamilnadu, Maharastra, Delhi, Chandigarh, Andhra Pradesh, Kerala and Karnataka are at the forefront of this activity. ${ }^{15}$ Targets for $11^{\text {th }}$ five year Plan (Indian plan system for development activities) is to collect 260,000 donated eyes (after death) for transplantation in persons with corneal blindness. ${ }^{16}$ West Bengal collected 2152 eyes in 2010 according to Union Health Ministry Officials. ${ }^{11}$

As early as 1905, doctors had discovered that corneal blindness could be cured by carrying out a corneal transplant. In most countries, especially in the developing ones, the numbers of corneas available do not meet the demand. In order to increase the potential for eye donation it may be imperative to promote awareness among potential donors and healthcare workers. ${ }^{27}$ Post-graduation medical students might serve as terminal care doctors of suitable eye donors; they would have a great opportunity to motivate patients or relatives to donate eyes. ${ }^{23}$

Data from the present study suggest that the level of awareness on eye donation/ corneal transplant among these students were high, as $98.9 \%$ students were aware that eyes can be donated only after death which was corroborative with the findings of some other studies in Delhi, ${ }^{17}$ Bangalore, ${ }^{18}$ Ahmedabad ${ }^{19}{ }^{19}$ Brahmapur, ${ }^{20}$ Karnataka, ${ }^{21}$ and Nagpur. ${ }^{22}$ However, the rate was somewhat lower (79.6\%) in another study among final year medical students of Delhi by Dhaliwal $U_{1}^{23} 86 \%$ among University students of Malaysia, ${ }_{1}^{24} 81 \%$ among secondary level students of North Kolkata ${ }^{25}$ and only $27.5 \%$ among medical students of Nigeria. ${ }^{27}$ Information by mass media could be related to the high level of awareness in these study participants.

When the study population were asked about the time of collection of cornea, a correct answer was given by $70.8 \%$ of students of this study, which was almost 
similar to the Delhi study (63.35\%) on medical students ${ }^{23}$ and the Karnataka study (61\%) on college students including medical students. ${ }^{21}$ The corresponding figures were only $41.1 \%$ in Delhi, ${ }^{17} 32.8 \%$ in Bangalore, ${ }^{18} 40.0 \%$ in Nagpur, ${ }^{22} 32.1 \%$ in North Kolkata ${ }^{25}$ and $37 \%$ in Kolkata. ${ }^{26}$ Lack of knowledge of this aspect on the part of doctors would result in unnecessary wastage of potential donor tissue. But it was encouraging that the Brahmapur study, ${ }_{1}^{20}$ the Ahmedabad study ${ }^{19}$ and the Nigeria study ${ }^{27}$ revealed that $90 \%$ of the medical students were aware of the ideal time of removing donated eyes (after death). In this study, 43.7\% respondents knew about the appropriate place of contact for an eye donation; which was higher than the Delhi study (27.2\%), ${ }^{17}$ the Bangalore study $(32.9 \%),{ }^{18}$ and the Nagpur study $(29.3 \%)^{22}$; but lower than the study by Nekar, et al. $(74.1 \%){ }_{1}^{21}$ Dhaliwal $(61.2 \%){ }^{23}$ Jena, et al. $(83.6 \%)^{20}$ and Sarkar et al. (66\%). ${ }^{26}$

In the present study, $90.6 \%$ of the medical students agreed that there is a shortage of eye donors in India and $76.0 \%$ students were willing to donate their eyes, whereas $4.7 \%$ had already pledged for eye donation. This represents a total of $80.7 \%$; corresponding with some other studies on medical and nursing students. ${ }^{17-22}$ This was a very encouraging feature which could motivate unwilling and undecisive individuals by showing the merits of eye donation.

Nobility was the prime reason $(87.7 \%)$ followed by pleasure to help the blind (75.5\%) felt by the willing donors of this study, a result that was almost similar to some other studies. ${ }^{17,18,21,22}$

The reasons for lack of eye donation were variable as perceived by the unwilling respondents. Of this study population, $74.4 \%$ told that lack of awareness was the main reason for people not to donate eyes. Similar results were obtained from other studies. ${ }^{17-22}$ Other reasons included objection by family members, body ill-treated by eye donation, religious restrictions, health problems, dislike of separating eyes from the body, etc. Other studies revealed similar reasons. ${ }^{17-19,21,22,27}$

If these students were well-informed about eye donation and corneal transplant, they could be expected to influence eye donation rates. Television was the most important source of information on eye donation (78.3\%) revealed from the present study. According to other studies also, television was the major source of information. . $^{1718,20,21,24-26}$

Using mass media to increase the awareness regarding corneal blindness and eye donation to treat it is not enough. There is a great need to educate students, as they are an important part of our society. If they are educated about the preventive and curative aspects of corneal blindness, they can spread the message among their friends and family members, thus acting as important motivators. It is also essential to dispel their misconception regarding eye donation.

\section{Conclusion}

The present study revealed that medical students were well aware of eye donation (98.9\%) with a favorable attitude towards it and most of them were inclined to pledge (80.9\%) for eye donation. The majority had correct knowledge of time of collection of eye $(70.7 \%)$ and $32.5 \%$ knew about the correct place of contact for eye 
donation. The perceived reasons for not donating eyes need to be considered while creating awareness about eye donation in the community.

Medical students can be actively involved as volunteers in eye donation campaigns and after proper training in counselling techniques, they can act as counsellors for eye donation activities.

In undergraduate courses, more emphasis should be given to eye donation and eye banking so that they will play a pivotal role in the eye donation movement in our country; the Hospital Corneal Retrieval Program (HCRP) will be successful by active involvement of medical students.

\section{References}

1. WHO. Definition of Blindness. International statistical classification of diseases injuries and cause of death,10 ${ }^{\text {th }}$ Revision (ICD-10).2006; 2nd edition; volume 2, chapter 7, H (54)9: p. 126.

2. Pascolini D, Mariotti SPM. Global estimates of visual impairment: 2010. Br J Ophthalmol 2012;96(5):5 614-18.

3. India: A Vision 2020 Handbook on Equipping a Secondary Eye Hospital. January 20, 2010. http://www.vision2020india.org.

4. Orbis: Eliminating Blindness In India. January 20, 2010. http://campaigns.orbis.org/Default.aspx?cid=5713\&lang=1

5. Government of West Bengal. A Mission to control blindness. Healthcare for All 2006;24-27.

6. Whitcher JP, Srinivasan M, Upadhyay MP. Corneal blindness: a global perspective. Bull World Health Organ 2001;79(3):214-221.

7. O'Connell C. Researchers aim to cut risk of cornea transplant rejection. The Irish Times, Tuesday, February 14, 2012.

8. Pinnamaneni N, Funderburgh JL. Concise review: stem cells in the corneal stroma. Stem Cells 2012;30(6):1059-1063. doi: 10.1002/stem.1100.

9. Tej Kohli. Corneal transplant - a new ray of hope for visually impaired. Healthy Living. Tej Kohli Foundation Cornea Transplant Mission, June 17, 2010 1:32 PM EDT.

10. PR News aggregation - National and International Press Releases Distribution September 19, 2010.

11. Sinha K. Only 30\% of donated eyes go to needy. Popular articles and stories for August 26, 2011. The Times of India, August 26, 2011.

12. Jose R. Present status of National Programme for Control of Blindness in India. Community Eye Health Journal. Indian Supplement 2008;21(65):103-104.

13. Gautam S. Eye donation drops across India. The Times of India, Chennai, September 1, 2011.

14. Nirmalya Charitable Trust: A vision for the Corneal Blind. Corneal blindness in India, April 26, 2012.

15. Verma R, Khanna P, Prinja S, Rajput M, Arora V. The National Programme for Control of Blindness in India. AMJ2011;4(1):1-3. http://www.readperiodicals.com/201101/2264625361.html\#ixzz21zjT3i2Y

16. Government of India. Ministry of Health and Family Welfare (Ophth./BC Section). Pattern of Assistance for National Programme for Control of Blindness during the11th Five Year Plan 2008, $21^{\text {st }}$ October.

17. Singh MM, Rahi M, Pagare D, Ingle GK. Medical students' perception on eye donation in Delhi. Indian J Ophthalmol 2007;55(1):49-52.

18. Gupta A, Jain S, Jain T, Gupta K. Awareness and Perception Regarding Eye Donation in Students of a Nursing College in Bangalore. Indian J Community Med 2009;34(2):122-125.

19. Patel AP, Satani DR, Parikh J, Patel JP, Shah RK. Perception of eye donation in medical students of Ahmedabad. Indian Journal of Applied Basic Medical Sciences 2011;13(16):23-28.

20. Jena $P$, Jena D, Dora J, Tripathy RM, Sahu T. A study on knowledge of first year medical students on eye donation. Journal of Community Medicine 2007;3(1):1-5.

21. Nekar MS, Lokare L, Gokhale SA, Godbole M, Mulkipatil SY, Venketesh M. Awareness of eye donation among college students of Hubli city, Karnataka. Internat J Biomed Res 2012;3(4):201-204. 
22. Anand DK, Tirmale H, Hukumchand MA. Awareness and Perception Regarding Eye Donation in Students of Medical College in Nagpur. Community/Social Ophthalmology-2 Free Papers. $69^{\text {th }}$ AIOC Proceedings, Ahmedabad 2011:762-766.

23. Dhaliwal U. Enhancing eye donation rates. Training students to be motivators. Indian J Ophthalmol 2002;50(3):209-212.

24. Bharti MK, Reddy SC, Tajunisah I, Ali NAM. Awareness and Knowledge on Eye Donation Among University Students. Med J Malaysia 2009;64(1):41-45.

25. Biswas J, Bandyopadhyay S, Das D, Mondal KK, Saha I, Ray B. A study on awareness about eye health care and eye donation among secondary level students of North Kolkata, India. Kathmandu Univ Med J 2010;8(31):317-320.

26. Sarkar K, Datta H, Maiti A, Singh M. Awareness of Medical Students Towards Eye Donation - The Missing Link. 64th AIOC (All India Ophthalmological Conference) 2006, Kolkata.

27. Okoye OI, Maduka-Okafor FC, Eze BI. What does the medical student know about eye donation/ corneal transplant? The University of Nigeria scenario. West Indian Med J 2010;59(1):41-44.

Submit your article now to the Asian Journal of OPHTHALMOLOGY a peer-reviewed online open access journal. www.asjoo.com 


\section{Xalatan: $\mid$ Xalacom}

\section{Efizer}

\section{One Drop a day helps them see what matters most..$^{1-4}$}

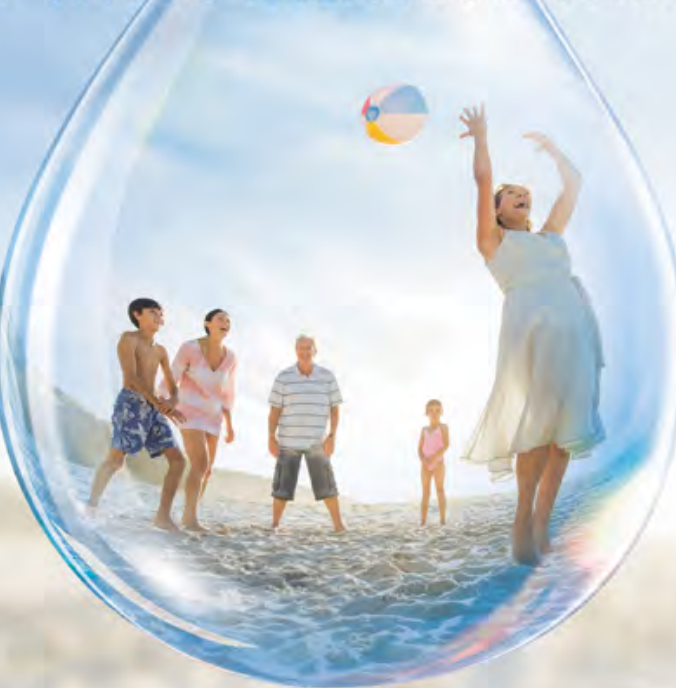

For over 10 years, Xalatan $^{\circledR}$ and Xalacom ${ }^{\circledR}$ have offered patients effective glaucoma treatments with the convenience of one bottle, one drop, once a day. ${ }^{1-4}$

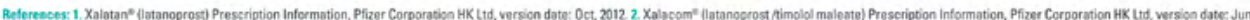

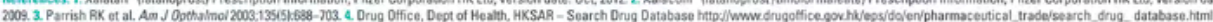

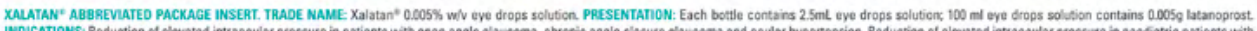

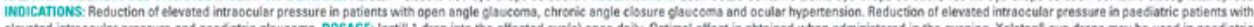

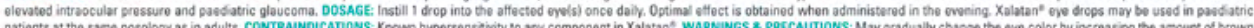
patients st the same posology as in adults. CONTRAUNOICANONS: Known hypersensitivity to any component in Xalatant. WARNiNGS \& PRECAUTIONS: May gradually change the eve color by increasing the amount of brown pigment in the inis. Patients should be monitored regularly and if the clinical situasion warrants, Xalazan" treatment may be discontinued. Xalatan* should be esed with caution in peri-operative peciod of cataract surgery patients, patients with a history of herpebic kerautis, aphakie pabents, in pseudophatic patients with torn posterior lens capsule or anterior chamber lenses, or in pubients with knowa risk factors for cystoid macular cedema, asthmatic patients. Experience to date shows that periorbital skin discolouration is not permanemt. Latanoprost may gradually champe evelashes and vellus hair in the treated eye and surrounding areas. Xalatan" contain. benzalkorium chloride. Contact lenses may sbsorb benzalkonium chloride and these should be removed before appiving Xalatan" but may be reinserted after 15 minutes. Ellicacy and safecty data in the age group < 1 year are

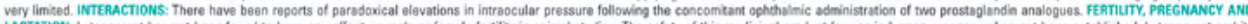
LACTarioN: Latanoprost hes not been found to have any effect on male or femele fertily in anima/ studes. The safeey of this medicinal product for use in human pregnency hes not been estabished. Latanoprost and its metabolites may pass into breast milk and Xalatan?" should therefore not be used in nutsing women of bresst feeding should be stopped. SiDE EFFECTs: Incteased iris pigmentation, mild to moderate conjunctival hyperaemila

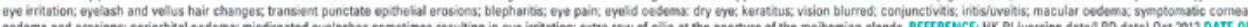

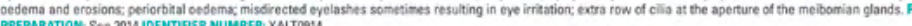

XULACOM" ABEAEVIATED PACKAGE INSERT. TRADE NAME: Xalacom" eye drops, solution 2.5mL, PRESENTATION: Each mi of Xalacom" contains 50meg latanoprost and $5 \mathrm{mg}$ timdlol. INDICATIONS: Reduction of imraoculat

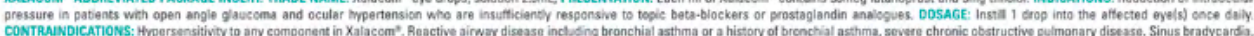

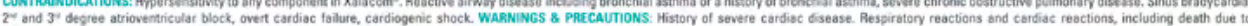

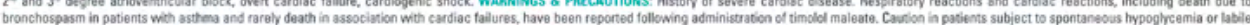

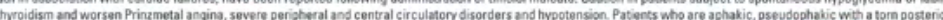
lens capsule or with known risk factors for macular oedema. Mary cause change in eve colour. Coenact lenses should be removed before asministration and mayte reinserted after 15 minutes INTERACTioNs: The use of twe

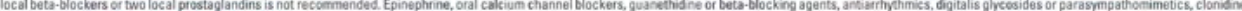

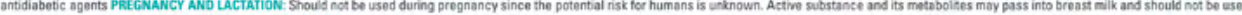

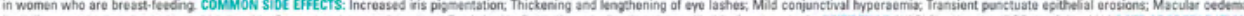

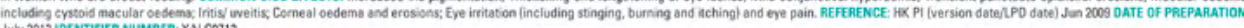
JUlY 2012 IOEENTFER NUMBBER: XALCO712

FULL PRESCRIBING INFORMATON IS AVAILABLE UPON REOUEST. 


\section{Asian Journal of}

Volume $13 \cdot$ Issue $4 \cdot 2014 \cdot 1560-2133$

www.asjoo.com www.kuglerpublications.com 